\title{
China in 2019
}

Party for the Party

\begin{abstract}
In a year of considerable pomp and circumstance at home, China's leaders continued to focus on how to deal with slowing economic growth, and the need for greater unity and support for the party (and Xi's) priorities and goals. Despite efforts to persuade others of the global benefits of China's rise, a number of key international actors seemed to increasingly think otherwise.
\end{abstract}

KEYWORDS: Xi Jinping, Chinese politics, trade war, Chinese Communist Party, China

The Chinese Communist Party has a lot of experience organizing showpiece events. But even by its own standards of expansive and expensive ceremony, the 7oth-anniversary National Day celebration in Tiananmen Square was particularly extravagant. Having attended the 35th-anniversary parade in 1984, I can only speculate how this much bigger affair tested the participants' stamina. It was the biggest yet in terms of the number of military personnel on parade ( 5,000$)$, with 160 aircraft and 580 pieces of military equipment paraded either on or above Chang'an Avenue, much of it on public display for the first time.

Some things looked familiar, though, with explicit echoes of previous events. The leader surveyed the troops through the open top of a black Red Flag limousine (albeit a newer model than the one Deng drove past in). Like Deng Xiaoping, Jiang Zemin, and Hu Jintao at National Day parades before

Shaun Breslin is Professor of Politics and International Studies at the University of Warwick, Coventry, UK. He is also co-editor of the Pacific Review, and currently holds a Leverhulme Major Research Fellowship to study the nature of China as a global power. The author gratefully acknowledges the support of the Leverhulme Trust through grant MRF-20I6-IO3, "China Risen? What is Global Power (and in What Ways Does China Have It)?” Email: <shaun.breslin@warwick.ac.uk.>

Asian Survey, Vol. 6o, Number I, pp. 2I-33. ISSN oo04-4687, electronic ISSN I533-838X. (c) 2020 by The Regents of the University of California. All rights reserved. Please direct all requests for permission to photocopy or reproduce article content through the University of California Press's Reprints and Permissions web page, https:/www.ucpress.edu/journals/reprints-permissions. DOI: https://doi.org/ I0.1525/AS.2020.60.I.2I. 
him, Xi Jinping greeted the assembled military forces by telling them they had worked hard (tongzhimen xinkule). And, as before, they replied in unison that they serve the people (wei renmin fuwu). Even here, though, there was a difference: instead of greeting him as "leader" (shouzhang) as had been the custom, $\mathrm{Xi}$ was greeted as zhuxi, which can be translated as chairman or president. As $\mathrm{Xi}$ is both chairman of the Central Military Commission and president of the state, he has two reasons for being greeted this way. But Jiang and $\mathrm{Hu}$ also held both ranks when they presided over previous parades marking the 1949 founding of the People's Republic of China, and while never formally head of the party or the state, Deng was chair of the Central Military Commission in 1984. Perhaps focusing on two changed Chinese characters resulting in one changed appellation for a leader is a little odd, given all the other ways in which Xi's leadership was highlighted and lauded during the parade (and indeed, in the media on the following days). But for some reason it seems strangely appropriate that in an event that was all about size, scale, and magnitude, the minutiae of a small linguistic modification might be important too.

Not surprisingly, the overarching message was one of success, national harmony, national rejuvenation, and national power delivered to and for the Chinese people by the Party, and in particular by Xi Jinping. It took place, though, against the backdrop of the escalation of a number of problems that had faced the leadership throughout the year. The most obvious and perhaps intractable was the political turmoil in Hong Kong, with a particularly violent set of protests marking National Day. February 2019 brought announcements of a new plan to tie Hong Kong to Macao, Shenzhen, and Guangzhou (and others) in a new cross-border Greater Bay Area that would become a new global innovation hub. By June, cross-border activity of a different kind, in the shape of a new extradition bill, had become the source of mass protests, which were themselves to evolve into manifestations of more general and fundamental concerns about the vanishing salience of having a border with the mainland.

What happened in Hong Kong in 2019 is so important that rather than deal with it here as one part of an overview of (mainland) Chinese politics, there is a separate article devoted to it in this issue of Asian Survey. Suffice it to say, though, that the question of how best to resolve what became a worsening crisis as the year progressed was a major challenge for $\mathrm{Xi}$ and his colleagues. So too were dealing with what seemed to be transforming from a "trade war" 
with the US to something bigger; growing international criticism of Chinese actions in Xinjiang; and how the ongoing transition to a new (slower) growth mode could be achieved without generating social problems-a task that the other challenges did not exactly make any easier.

\section{STOPPING OTHERS STOPPING CHINA}

One of the frequently reported parts of Xi's speech on National Day was the assertion that "no force can stop the Chinese people and the Chinese nation forging ahead." It would seem unnecessary to make such a statement unless there was a clearly identified force trying to do so. And it is probably fair to suggest that in Xi's mind, the US under President Trump was indeed such a force. There were a couple of times in 2019 when it looked as if the trade war that had begun the previous year might be rather short-lived. After a meeting with $\mathrm{Xi}$ at the Osaka G2O Summit in June, Trump announced a "truce" to allow time to find a settlement, and said that China would soon start buying "a tremendous amount of food and agricultural product" to reduce the trade deficit. A quick agreement, though, was not forthcoming. As a result (and not surprisingly), when a similar ceasefire was announced in October, it was not clear whether this presaged a return to the status quo ante or was a simple pause before the escalation of action later in the year.

Moreover, there was more to US-China tension than just the imposition of a range of tariffs by both sides. In April and May, some Chinese academics working on security issues had their US visas revoked as part of a step to prevent Chinese military and military-related personnel undertaking study or research in the US. A tweet from Trump in August "ordered" US firms to look for alternatives to dealing with China (though it seems that tweets do not yet carry any formal legal authority). In August, the US designated China a "currency manipulator" as the value of the RMB fell below seven to the dollar (but ironically just after the IMF had calculated that it was now pretty much correctly valued), and tighter controls on Chinese investment projects were also mooted. ${ }^{1}$ When in November Trump signed the Hong Kong

I. For a good overview of how these tensions evolved, more details on the examples listed below, and their potential consequences, see Matthew Goodman, "Beyond the Brink Escalation and Conflict in U.S.-China Economic Relations," Center for International and Strategic Studies, Washington, DC, September 2019, <https://csis-prod.s3.amazonaws.com/szfs-public/publication/ I90925_Goodman_BeyondBrink_WEB.pdf>. 
Human Rights and Democracy Act mandating an annual review of the extent of Chinese political freedom to guide future trade relations, it's fair to say that many in Beijing thought that this was a show of strength that was about more than just politics in the SAR.

Some Chinese companies and individuals were also blacklisted or otherwise punished by Washington for their involvement in the surveillance and repression of Uighurs in Xinjiang and the breaking of US sanctions on exporting oil from Iran. The former points to the extent to which the internationalization of the Xinjiang issue continued to accelerate in 2019. In addition to the US's unilateral action, in July the UN representatives of 22 other liberal democracies wrote to the UN High Commissioner for Human Rights condemning Chinese policy. ${ }^{2}$ This did not include the US, as Trump had previously withdrawn it from the UN Human Rights Council. Nor, as Putz notes, did the note include any of the Central and Eastern European states at the west end of the Belt and Road that met with China as part of what became the $17+\mathrm{I}$ process (with the addition of Greece to the original I6) in January 2019. ${ }^{3}$

China responded with a form of internationalization of its own by reporting that 37 countries had signed a letter condemning those who wanted to "politicize" human rights and interfere in Chinese sovereign affairs. A group of international media representatives were also invited to visit Xinjiang to meet with those undergoing "re-education"—not always generating the conclusions that the trips were presumably intended to generate. ${ }^{4}$ China also produced two white papers, "Historical Matters Concerning Xinjiang" (in July) and "Vocational Education and Training in Xinjiang" (in August). These white papers and the way Chinese officials have engaged international audiences more generally point to a significant shift in Chinese policy in less than two years, from denying the existence of the program to trying to influence how it is reported and understood.

2. Catherine Putz, "Which Countries Are For or Against China's Xinjiang Policies?" The Diplomat, July 15, 2019, <https://thediplomat.com/2019/o7/which-countries-are-for-or-againstchinas-xinjiang-policies/>.

3. Founded in 2012, the $16 / 17+\mathrm{I}$ process was designed to increase interaction and cooperation between China and countries of Central and Eastern Europe (all but Greece, former Communist Party states, and component parts of former larger ones, like Yugoslavia). It has a secretariat based in Beijing and holds an annual summit (in 2019, in Dubrovnik).

4. See, for example, the BBC's report of its visit in June, "Inside China's 'Thought Transformation' Camps," <https://www.bbc.co.uk/news/av/world-asia-china-4866722I/inside-china-sthought-transformation-camps $>$. 
Sanctions on Iranian oil exporters were introduced three weeks after the September announcement of Chinese investment of up to US\$ 400 billion in Iranian oil and transportation industries. We are probably on safe ground in assuming that geopolitical considerations played at least some role in shaping Chinese choices of international partners in this case. It is also an example that reminds us that the escalation of tension and areas of contention were not just from the US side. In addition to reciprocal economic action (and reports of potential reciprocal visa denials) imposed by the Chinese authorities, Canadian citizens Michael Kovrig and Michael Spavor remained in detention in China in 2019. Both had been detained for supposedly endangering China's national security the previous December, shortly after the Canadian authorities arrested Huawei's chairwoman, Meng Wanzhou, at the request of the US authorities (for alleged crimes that were also related to trade with Iran). So, just as the economic consequences of the trade dispute have important spillover effects for other countries (particularly those providing inputs to what become Chinese exports), the diplomatic consequences of these tensions can spill over to others as well.

The second China Import Expo, held in Shanghai in November, did not open with quite the same fanfare and prominence its predecessor had in 2018. Even so, it did attract French President Emmanuel Macron and the premiers of Jamaica, Serbia, and Greece to its opening ceremony. Xi used the occasion to once again reaffirm China's commitment to openness, in terms of both the global trading system in general and the further opening of the Chinese economy in particular. In addition to the rhetoric, a new Foreign Investment Law passed in March (operational from January 2020) and State Council investment guidelines issued in November were both hailed in China as creating a level and transparent playing field for foreigners to compete with domestic actors in the Chinese market.

\section{SIGNALLING INTENT: CHINA'S FUTURE GLOBAL ROLE}

Time will tell, of course, whether national-level legislation translates into realities on the ground, not least as local governments weigh the consequences of allowing competition with domestic producers. Whatever happens in the future, in the immediate term the Expo and the way the new law and guidelines were announced and publicized performed important signaling functions, promoting an idea of China and its future that its leaders 
want to project to both domestic and international audiences. They also used other important showpiece events throughout the year as platforms for messages about China's strategic intent. These included presentations by $\mathrm{Xi}$ at the Second Belt and Road Forum in April, the Conference on Dialogue of Asian Civilizations in May, at the Shanghai Cooperation Organization's Heads of State Meeting in June, and the Conference on Interaction and Confidence-Building Measures in Asia (also in June). Foreign Minister Wang Yi was also active in promoting the preferred story of China's global role at the Forum on China-Africa Cooperation follow-up meeting in June, and at the UN in September. ${ }^{5}$

China also produced a new white paper on "China and the World in a New Era" to commemorate the 7oth anniversary. ${ }^{6}$ As with the similar use of similar events in 20I8, individually and collectively, they presented a picture of how China's growth had been beneficial to the rest of the world, creating jobs and economic stability (and therefore contributing to global peace) in a period when the economies of the previous heartlands of the global economy were in decline (or crisis), and previous promoters of globalization were turning inward. As such, so the message goes, it is China that is now "on the right side of history" and an "important upholder of the international order" in the face of unilateralism and protectionism elsewhere. ${ }^{7}$

However, despite this status quo message, in a People's Daily editorial Wang Yi also affirmed China's determination to take the lead on promoting global governance reform. ${ }^{8}$ If this sounds like a contradictory set of positions, then the key is understanding what exactly the international order is that China is committed to upholding. It is neither a US-led one nor a liberal international order. Rather, it is one that is based on the sovereignty principles that underpin the UN Charter as understood and manifest in China by

5. The Chinese Foreign Ministry offers transcripts of speeches by Xi, Wang and other major leaders on foreign policy issues at <https://www.fmprc.gov.cn/mfa_eng/wjdt_665385/zyjh_66539I/>.

6. State Council, "China and the World in the New Era," September 27, 20I9, <http://english. www.gov.cn/archive/whitepaper/201909/27/content_WS5d8d8of9c6dobcf8c4cI42ef.html>, accessed September 30, 2019.

7. Wang Yi, "Remarks at Ministry of Foreign Affairs 2019 New Year Reception," January 3I, 2019, <https://www.fmprc.gov.cn/mfa_eng/wjdt_665385/zyjh_66539I/tr634534.shtml>, accessed February 4, 2019.

8. Wang Yi, "Puxie zhongguo tese daguo waijiao de shidai huazhang" [The era of writing great power diplomacy with Chinese characteristics], Renmin Ribao [People's Daily], September 23, 2019, <http://paper.people.com.cn/rmrb/html/2019-09/23/nw.Diroooorenmrb_20190923_I07.htm> accessed October I, 2019. 
the Five Principles of Peaceful Coexistence. It is an order that would be built around strengthening some of the existing pillars of global order, like the UN, the G2O and a reformed WTO, but not those that privilege Western/developed countries' preferences and power. The order China is committed to emphasizes the fundamental importance of diversity and pluralism in the norms and principles that underpin how the world is ordered (as well as in domestic political and economic structures), rather than accepting liberal norms as the basis of universalist positions. What is perceived and explained as a status quo position in China can look rather different to those who are committed to a different type of order.

This understanding of the importance of diversity based on national conditions was used to explain in another white paper (on human rights) how China had not only delivered fundamental rights for its own people (the rights to national sovereignty, subsistence, and development) but was now, through this promotion of diversity and development cooperation, a key actor "Advancing the International Cause of Human Rights." It also noted that Chinese representatives had, successfully in some cases, argued for the inclusion of Xi Jinping's "Community of Shared Future for Humankind" in a number of UN resolutions. This Janus-faced position was also evident in yet another white paper, the first on national defense since 20I5. Like its predecessors, it was partly designed to convince others that China was and would always be defensive and reactive in developing its military forces, but resolute in defending the country's rightful interests. But these include ever-greater overseas interests, which extend the scope of Chinese defense far beyond its sovereign borders. For Erickson, the takeaway message is an "ambition, assertiveness and resolve" to "make China great again by all means necessary." 10

This ever-more-proactive Chinese position, combined with a reassessment of China's growing economic power, resulted in an important shift in official EU policy toward China in 2019. While recognizing that China was a potential partner in some issue areas, such as combating climate change, a new strategy paper designated it an "economic competitor in the pursuit of

9. State Council, "Seeking Happiness for People: 70 Years of Progress on Human Rights in China," September 22, 2019, <http://english.www.gov.cn/atts/stream/files/5d877404c6docc30o eea773a>, accessed September 30, 2019.

Io. Andrew Erickson, "China's Defense White Paper Means Only One Thing: Trouble Ahead," The National Interest, July 29, 2019. 
technological leadership" and "a systemic rival promoting alternative models of governance." 11 This might fall short of the idea of China as the comprehensive and holistic strategic competitor, as Trump labeled it in 2017 (while being more substantial than the idea of China becoming a strategic partner, which Trump suggested at the G2o summit). But it reflects a very significant reappraisal of the potential consequences of China's rise in at least some parts of Europe (though not all of it, as Italy's embrace of China in the summer of 2019 shows).

\section{NEW NORMAL OR ABNORMAL ECONOMICS?}

It is impossible to know the precise impact of the trade war and the broader tensions with the US on the Chinese economy, and how much of the relatively slower growth was instead down to ongoing structural changes in the Chinese economy. What is clear is that whatever that impact was, it did not make the job of adapting to what Xi had previously called the "new normal" of slower (but hopefully more sustainable) growth any easier. The annual Government Work Report made by Premier Li Keqiang in March referred to the main economic indicators as falling "within an appropriate range." Growth has been steadily declining for years, and China's leaders have also been preparing the people for a period of slower growth for quite some time. So GDP growth of $6.6 \%$ for 2018 was not overly surprising in itself. But the fact that it was the lowest figure since 1990, and about one-third lower than the 9.5\% average over the previous two decades, gives some indication of the significance of the direction of travel. Li argued that China faced "a profound change in our external environment," including "setbacks in economic globalization, challenges to multilateralism, shocks in the international financial market, and especially the China-US economic and trade frictions."

$\mathrm{He}$ also argued that things were going to get worse: "A full analysis of developments in and outside China shows that in pursuing development this year, we will face a graver and more complicated environment as well as risks and challenges, foreseeable and otherwise, that are greater in number and size.

II. European Commission, "EU-China: A Strategic Outlook," High Representative of the Union for Foreign Affairs and Security Policy Joint Communication to the European Parliament, the European Council and the Council, March I2, 2019, <https://ec.europa.eu/commission/sites/ beta-political/files/communication-eu-china-a-strategic-outlook.pdfs. 
We must be fully prepared for a tough struggle. The difficulties we face must not be underestimated."12

And he was right. Annualized growth in the first three quarters of 2019 fell to $6.4 \%, 6.2 \%$, and $6 \%$, respectively. The latter two figures were even lower than in the second half of 2008, when Chinese exports collapsed as a result of the global financial crisis, and you have to go back to 1989 and 1990 to find lower official annual growth rates (and before that, to 1982). Of course, these are still rates that many countries would be delighted with, and $6 \%$ more of the Chinese economy in 2018 generates more actual extra income than the higher growth rates (from a lower base) did in previous years. But given the past emphasis on growth rate as an indicator of success, and what it could mean for the ability to deal with current problems (like debt) in the future, it is easy to see why $\mathrm{Li}$ was not underestimating the scale of the difficulties.

The review of China in 2018 in this journal spent some time pointing to a double dilemma facing Chinese policymakers. The first dilemma is how to manage the transition to a new growth mode without too many dislocations; the second is a more specific problem of balancing the desire to reduce debt (not least local government debt) with the need to spur growth. Both were key features of economic policy in 2019 too, with rumors of high-level disagreements over which way the balance in the second of these dilemmas should tip. Record-high bank loans in January were followed by Li's announcement at the National People's Congress that local governments would get an extra RMB 800 billion (roughly US\$ II4 billion) worth of bonds to issue during 2019 to make a grand total of RMB 2.15 trillion (around US\$ 307 billion) available to both fund new projects and offset existing debt risks. The central government also doubled the amount of money assigned for new investment schemes, and as in previous years, some of the liquidity regulations on banks were reduced, allowing them to extend more loans. These and other measures Li has called "advanced adjustments and finetuning," though we could perhaps also think of them as constituting a mini-stimulus. ${ }^{13}$ Or perhaps we should not worry too much about what

I2. Li Keqiang, "Report on the Work of the Government," March I6, 2019, <http://english. www.gov.cn/premier/speeches/2019/o3/16/content_28I476565265580.htm>, accessed April 19, 2019.

I3. For details of the various measures, see Amanda Lee, "China's Total Debt Rises to over 300 per Cent of GDP as Beijing Loosens Borrowing Curbs to Boost Growth," South China Morning Post, July 17, 2019, <https:/www.scmp.com/economy/china-economy/article/301899i/chinas-total-debtrises-over-30o-cent-gdp-beijing-loosens>. 
it's called and simply accept that these dilemmas are likely to be part and parcel of economic management in the new normal for some time to come.

\section{MORE CONTROL (AGAIN)}

Li's government work report suggests that there was a slightly stronger emphasis on potential problems in 2019 compared to the recent past. If there was, it's easy to see why. The background of the trade war and international criticism of what was happening in Xinjiang were evidence of a broader change in the international environment, with the consequences of China's rise now being seen as potentially more negative than before, in more places than before. What was happening in Hong Kong certainly didn't help either. At home, the desire for everything to go as well as it could for the $7 \mathrm{O}^{\text {th }}$ anniversary celebrations during a period of slowing growth provided a particularly important challenge. That 2019 also marked another anniversary might also have played a role. In the end, though, the zoth anniversary of June 4 passed with little fuss and attention (except in Hong Kong), although the death of Li Peng on July 22, 2019 created the opportunity for a number of Western media outlets to revisit it (and Li's role in it) in their obituaries.

Showcasing China's successes is one tried and trusted way of trying to offset problems in other areas. Ensuring ever-greater conformity and unity of purpose is another. At the beginning of the year, $\mathrm{Xi}$ was reported to have complained of a "slackness of spirit" and lack of ability among party members at a seminar for party elites at the Central Party School. ${ }^{14}$ In September, he returned to the Central Party School to address more junior cadres and told them that the majority must "undergo strict ideological refinement" and political training and learn the skills of "struggle" to best be able to deal with both "rare historical opportunities" and "a series of major risks." ${ }^{15}$

However, there is more to conformism than just what happens within the party. There was a consistent emphasis throughout the year on the

14. Chun Han Wong, "Xi Jinping Works to Stifle Dissent amid Concerns about China's Economy," Wall Street Journal, March 3, 2019.

I5. "Xi Jinping delivered an important speech at the opening ceremony of the training course for young and middle-aged cadres of the Central Party School (National School of Administration), carrying forward the spirit of struggle, strengthening the struggle, and striving for the goal of 'two hundred years.' Wang Huning attended." Xinhuanet, September 3, 2019, <http://www.xinhuanet. com/politics/20I9-09/03/c_II2495608I.htm>, accessed October 3, 2019. 
importance of unity among the Chinese people as a whole, and of everybody falling in line behind the party's official version of the truth. Shortly after the annual party meeting in November (the Fourth Plenum), the Central Committee published its "Outline for the Implementation of Patriotism Education in the New Era." ${ }^{16}$ Like similar movements before it, one key intention is to try to make it impossible to separate love for the country from love (and gratitude) for the party and its leadership. The link is made explicitly: "The fate of the motherland is inseparable from the destiny of the party and the destiny of socialism. In contemporary China, the essence of patriotism is to maintain a high degree of unity between patriotism, and love for the party and the love of socialism."

Thus, patriotic education entails primarily learning about and lauding the party. Given the extent to which the party under Xi has tried to enforce its and his control in recent years, you could be forgiven for thinking that there is no need to intensify this project in 20I9. But intensified it was, and it looks likely to be further strengthened in the future too.

\section{CHINA'S NOT-SO-SOFT POWER}

Although this overview has largely tried to avoid overlapping with the analysis in this issue of Hong Kong's turbulent 2019 provided by Professor Sonny Shiu-Hing Lo, there is a reason to return to it here. In October the general manager of the Houston Rockets basketball team tweeted support for the Hong Kong demonstrators. This generated a backlash in China and a hemorrhaging of Chinese support not just for his team (and purchases of their merchandise) but for the National Basketball Association (NBA). Earlier in the year, the firms Versace, Coach, Givenchy, ASICS, Samsung, Calvin Klein, Swarovski, and Fresh had all apologized after having been "exposed" as appearing to suggest that one or more of Hong Kong, Macao, and Taiwan were separate entities, not a sovereign part of the PRC. But this did not happen in the NBA case.

The refusal of the NBA commissioner to apologize (after it first appeared that he might), and his commitment to maintaining the right to free speech, marks the NBA as different from other companies that have been deemed by either the Chinese state or the online community to have not respected 
Chinese sovereignty. ${ }^{17}$ While this might say something about the NBA's own dominance and power in the global basketball market, it also draws attention to how Chinese preferences and preferred narratives are being externalized. Trying to influence how those outside China talk about China and its rise is often considered part of China's "soft power" strategy. The goal is to establish preferred Chinese narratives as the basis for discussing China rather than those that are driven by outsiders. The expansion and internationalization of Confucius Institutes and the Chinese print, television, and radio media are typically considered key means of pursing these objectives.

How a state-driven and state-funded project can be considered "soft" has long puzzled me. But in most of the above cases, it is the size of the Chinese market and the purchasing power of Chinese consumers that seem likely to have generated the remedial actions. In a year where a number of US universities decided to close their Confucius Institutes, ${ }^{18}$ and China Global Television News was accused of breaching UK reporting rules on impartiality, it was China's rather hard market power that seemed to be getting results, with its agents of "soft power" generating more concern than acquiescence and friendship.

\section{CHINA IN 2019: MORE OF THE SAME?}

Given all that happened in Hong Kong in 2019, it would be ridiculous to argue that it was a year when not much changed. But if you can put Hong Kong to one side (and that admittedly is a big ask) then we can see some key continuities. Growth continued to slow, and the government continued to struggle both to find a way to reverse the slowdown, and a means of moving to a new economic paradigm while preventing negative consequences. The importance of enhancing the party's ability to govern and lead was reasserted, as was the need for the broader population to fall in line and internalize the party's aspirations. Tensions with the US continued, which are not going to simply go away, even if a trade deal can be reached. The party

I7. Mark Dreyer, "China NBA: How One Tweet Derailed the NBA’s China Game Plan," BBC Online, October Io, 2019, <https://www.bbc.co.uk/news/world-asia-china-49995985>.

I8. While there has long been concern that these were unduly influencing debate on China in the US, the 2019 National Defense Authorization Act gave an added impetus by including a clause that prohibits any institution that hosts a Confucius Institute from receiving federal funding to support Chinese-language teaching. 
leadership continued to project its preferred image to a global and domestic audience, and in the West at least, it continued to have little purchase, with suspicion of China tending to increase instead, in terms of both Chinese global ambitions and Chinese ability to influence domestic political debates in other countries. History has shown us, though, that just as China seems to be settling in to a steady and predictable pattern of behavior and development, things can very quickly change. There is no suggestion, then, that we are settling into a new normal of not just economic but also political continuity. And that's without bringing the question of Hong Kong's future back into the equation. 